\title{
Taoism and Religious Coping
}

\section{Lai LCH*}

Department of Counselling and Psychology, The Hong Kong Shue Yan University, China

*Corresponding author: Lufanna Ching-han Lai, Department of Counselling and Psychology, The Hong Kong Shue Yan University, Hong Kong, China, Email: chlai@hksyu.edu

Mini Review

Volume 6 Issue 1

Received Date: January 28, 2022

Published Date: February 18, 2022

DOI: $10.23880 / \mathrm{mhrij}-16000163$

\section{Abstract}

In facing life adversity, coping strategy is adopted to resume control over the environment; otherwise, mental health and wellbeing will be adversely affected. In this light, it is found that religion affects coping, as for those people having religious belief, their coping strategies will primarily be based on their affiliated religion. This study aims to examine the religious coping of Taoism - a religion indigenous to China. The devotional activities lay down in Taoism permit people to interact with the supernatural forces in the universe. Through the rituals, people can psychologically experience an enhanced control over the environment which results from associating vicariously with the deities. Given the scarcity of study on the Eastern religion in extant literature, this study contributes to the understanding of the religious coping in Taoism, a religion mainly practiced in China.

Keywords: Perceived Control; Religious Coping; Secondary Vicarious Control; Taoism

\section{Introduction}

It is generally agreed that life adversity is inevitable in human life. In this light, some studies have demonstrated that feeling no or low degree of control over the adverse situations will exert deleterious effect on mental health and wellbeing [1-3]. Correspondingly, to regain a sense of control over the environment, coping strategy should be adopted so that human mental health and wellbeing will be maintained or less affected. In this context, it is found that religion affects coping [4]. Hence, for those people having religious belief, their coping strategies will primarily be based on their affiliated religion, given that their value system will be highly affected by the religious teachings [5]. In the field of psychology of religion, despite a converging body of research on religious coping, most of them are related to Christianity [6-8], a religion originated in the West. Given the scarcity of study on the Eastern religion, this study will investigate the religious coping in Taoism, a religion mainly practiced in China.

\section{Life Adversity and Perceived Control}

Perceived control can be conceptualized as individual judgments of the extent that desired outcomes can be achieved, and potential misfortunes can be guarded against $[6,9,10]$. Basically, there are two different approaches to increasing control in the encounter of life adversity i.e., primary control and secondary control [4]. According to Rothbaum F, et al. [11], primary control involves actively changing the environment to fit the needs and desires of the self, whereas secondary control involves changing one's own thoughts and feelings to fit the environment. Correspondingly, secondary control can be more helpful in low-control situation [6,12]. In Taosim, when the adherents encounter adverse situation, they will engage in religious 


\section{Mental Health \& Human Resilience International Journal}

activities i.e., the rituals, from which to obtain a sense of control through the interaction with the supernatural forces in the universe. Such kind of religious coping can be understood as the secondary vicarious control, the attempt to associate or closely align oneself with powerful others e.g., a god or deity, that enables the individual to join in their power $[6,11]$.

\section{Tao and Supernatural Forces}

Taoism is a religion indigenous to China. The main tenet of Taoism is the belief in Tao. It is difficult to translate the exact meaning of Tao into English, but in the most general terms, it can be translated as the path or the way $[5,13,14]$. Taoism believes in the existence of supernatural being such as gods and demons. In fact, every being in the universe, irrespective of human or spirit is naturally an expression of Tao. In this light, both human and spirit are made up of qi $[15,16]$. When qi is diluted, it is indefinite potential; when it is condensed, it becomes life [15]. Thus, the formations of different beings are primarily the compositions of differential levels of the purity and weight of qi [17]. As such, every different kind of being is only manifesting a different force of the Nature [18].

In Taoism, everything in the universe, both seen and unseen is controlled by a god. In this term, there are more than three thousand gods in the world [17]. For example, gods of heaven and earth; gods of mountain and river; gods of trees and flowers; gods of thunder and lightning, the gods of the regions of earth-North, South, East, West and Center; and even the gods for common and everyday things such as walls and ditches. Moreover, some of the gods were once human i.e., the ancestors and heroes [17]. The Chinese like to revere their ancestors and those people who did great deeds as elevating them to the status of gods.

Furthermore, the Taoists believe that the gods are challenged by demons that plague the natural and human worlds. These demons may be natural forces such as typhoons, epidemics, fires and droughts. They may also be men or women who have died violently or meaninglessly. Sometimes, they are 'orphan souls' i.e., people who have no families to remember them after death; or those who have been improperly buried after death without any ancestor tablet to keep their memory alive. To achieve the goal of being remembered, these 'orphan souls' use the forces of nature to draw human's attention. As such, these unhappy demons roam the world and cause sickness and other hardships.

\section{Interaction with Supernatural Beings}

Tao is believed to be an expression of the continuous interaction of different beings from heaven (deities), earth (demons) and humanity [17]. The Taoists believe that by means of rituals, they are able to establish relationship with the spirits, which in turn help to keep their earthly world in order and harmony. This kind of control is perceived as the secondary vicarious control technique [6,11]. Rituals are the formal acts which make up religious observance important for the worship of Taoism deities. Although there are various kinds of rituals, they commonly share the objectives of allowing the Taoists to communicate with the deities who have supernatural power, as well as to petition them for aid in relation to worshippers' needs, problems and wishes Leung TW, et al. [17]. Hence, in facing life adversities perceived as too hard to tackle, the Taoists are not powerless, as they can regain a sense of power by associating with the powerful forces (gods) through the rituals. As such, some examples of the rituals are cited as follows: The most important Taoist ritual is the Jiao. Jiao means offering to the gods. Jiao is the largest scale ritual that comprises a series of individual rites conducted for different purposes, lasting for at least three days. During the performance, the highest gods of heaven, earth and humanity will be invited by the priests to be present at the ritual [17]. Human requests are then raised out to them for their assistance, including the enhancement of the welfare of living people, the preservation of the community, the salvation of wandering souls, expelling disasters and misfortunes, and driving away evils [17].

Apart from Jiao, it is common for the Taoists to hold the ancestor rites with a view to memorizing them, as well as asking for their blessing on health and prosperity. There are also the rites related to birth and death. For instance, a woman who is expecting a child can make offering to a specific deity to ensure a safe delivery and a healthy baby $[18,19]$. Concerning death, Taoism believes that the spirits of human continue to survive after bodily death and, subsequently, need to face judgment from the god concerned followed by punishment for any misdeeds on earth. In this context, the ritual delivered by the survivors on earth can buy the dead person a reprieve from divine punishment. The Taoists do not worship demons. However, to avoid the bringing of bad luck and hardship, the Taoists can bargain with the demons by asking a god to intercede.

\section{Conclusion}

In sum, when the Taoists encounter life adversities out of their control and/or face adverse situations where they can exert no influence, they can rely on, and appeal to, the supernatural powers for assistance $[20,21]$. In this connection, the rituals are the religious attempts which permit the Taoists to associate themselves vicariously with the powerful forces. In turn, the perception of enhanced control is the outcome of participating psychologically in the control that the deities exert. 


\section{Mental Health \& Human Resilience International Journal}

\section{Recommendations}

Some recommendations for future research are suggested as follows: First, this study provides a conceptual framework for understanding the control strategy adopted by the Taoists. Hence, empirical study to verify its validity is warranted. Second, appealing to supernatural powers in facing adversity may only be one of the Taoist coping strategies. In this light, to achieve a more comprehensive understanding, further investigation should be conducted, in terms of both primary and secondary control, to explore the full repertoire of coping strategies adopted.

\section{References}

1. Bailis DS, Segall A, Mahon MJ, Chipperfield JG, Dunn EM (2001) Perceived control in relation to socioeconomic and behavioural resources for health. Soc Sci Med 52(11): 1661-1676.

2. Kondo A, Abuliezi R, Naruse $\mathrm{K}$, Oki $\mathrm{T}$, Niitsu $\mathrm{K}$, et al. (2021) Perceived Control, Preventative Health Behaviors, and the Mental Health of Nursing Students During the COVID-19 Pandemic: A Cross-Sectional Study. The Journal of Health Care Organization, Provision, and Financing 58: 1-11.

3. Wallhagen MI, Brod M (1997) Perceived control and well-being in Parkinson's disease. West J Nurs Res 19(1): 11-25.

4. Greenberg JS (2021) Comprehensive stress management, $15^{\text {th }}$ (Edn.), McGraw Hill.

5. Olpin M, Hesson M (2020) Stress Management for Life: A research-based, experiential approach, $5^{\text {th }}$ (Edn.), CA: Wadsworth, Cengage Learning.

6. Lai LCH (2021) Christianity and subjective wellbeing: A study of Hong Kong. Psychology and Behavioral Sciences 10(1): 56-62.

7. Pargament KI, Tarakeshwar N, Ellison CG, Wulff KM (2001) Religious coping among the religious: The relationships between religious coping and well-being in a national sample of Presbyterian clergy, elders, and members. Journal for the Scientific Study of Religion 40(3): 497-513.

8. Park C, Cohen LH, Herb L (1990) Intrinsic religiousness and religious coping as life stress moderators for Catholics versus protestants. J Pers Soc Psychol 59(3): 562-574.

9. Endler NS, Kocovski NL, Macrodimitris SD (2000) Coping, efficacy, and perceived control in acute vs. chronic illness. Canada: York University.

10. Heckhausen J (1999) A model of developmental regulation across the life span. In Developmental regulation in adulthood. Cambridge University Press, pp: 85-101.

11. Rothbaum F, Weisz JR, Snyder SS (1982) Changing the world and changing the self: A two-process model of perceived control. Journal of Personality and Social Psychology 42(1): 5-37.

12. Band EB, Weisz JR (1988) How to feel better when it feels bad: Children's perspectives on coping with everyday stress. Developmental Psychology 24(2): 247-253.

13. Da Silva Guimarães Martins Da Costa L (2022) Transdisciplinarity Theory Through Plato Philosophy, Taoism, Alchemical Tradition and Jungian Psychology. Transdisciplinary Journal of Engineering Science 13: 1-20.

14. Li H, Cao Y (2021) Move with the Flow: Metaphorical Perspectives on Time in Chinese Taoists and Atheists. The International Journal for the Psychology of Religion 31(4): 225-234.

15. Loy CY (1997) The supreme way: Inner teachings of the Southern Mountain Tao. CA: North Atlantic Books.

16. Robinet I (1997) Taoism: Growth of a religion. California: Stanford University Press.

17. Leung TW, Ng C, Chan HF (2007) Tao, Jiao. The Hong Kong Taoist Association.

18. Hartz PR (1993) Taoism: World religions. New York: Facts on File, Inc.

19. Smyth KB, Koenig HG (2014) Could spirituality and religion promote stress resilience in survivors of childhood trauma?. Issues Mental Health Nurs 35(4): 251-256.

20. Dolcos F, Hohl K, Hu Y, Dolcos S (2021) Religiosity and Resilience: Cognitive Reappraisal and Coping SelfEfficacy Mediate the Link between Religious Coping and Well-Being. Journal of Religion and Health 60: 28922905.

21. Koenig HG, McCullough ME, Larson DB (2001) Handbook of religion and health. Oxford, UK: Oxford University Press. 